\title{
Akılcı İlaç Kullanımına İlişkin Bir Araştırma
}

\author{
Arş. Gör. Dr. Fatih ŞANTAŞ \\ Bozok Üniversitesi, İktisadi Ve İdari Bilimler Fakültesi \\ Sağlık Yönetimi Bölümü
}

Akılcı İlaç Kullanımına İlişkin Bir Araştırma

\section{Öğr. Gör. Bünyamin DEMİRGİL}

Cumhuriyet Üniversitesi, İktisadi Ve İdari Bilimler Fakültesi

Maliye Bölümü

bdemirgil@cumhuriyet.edu.tr I

\begin{abstract}
Özet
Amaç: $\mathrm{Bu}$ çalışma, üniversite öğrencilerinin akılcı ilaç kullanma davranışlarının belirlenmesi amacıyla yapılmıştır. Yöntem: Araştırmanın evrenini bir devlet üniversitesinin iktisadi ve idari bilimler fakültesinde öğrenim gören 800 birinci ve dördüncü sınıf öğrencileri oluşturmaktadır. Araştırma, 15 Mayıs-15 Haziran 2016 tarihleri arasında gerçekleştirilmiş ve araştırmaya 602 kişi dâhil olmuştur. Bulgular: Bu araştırma öğrencilerin \% 52 'sinin son bir ay içerisinde, \% 12'sinin sürekli ve \% 17'sinin sık ilaç kullandığı, sık ilaç kullanan öğrencilerin \% 13'ünün kullandığı ilacın adını bilmediği ve en sık kullanılan ilacın ağrı kesici olduğunu göstermektedir. Çalışma ile katılımcıların \% 27'sinin reçetesiz olarak ilaç aldığı, \% 23'ünün reçeteleri okumadığı, \% 24'ünün ilaçları zamanında kullanmadığı, \% 13'ünün kullandığı ilacın dozunda değişiklik yaptığı, \% 10'unun stresli durumlarda ve \% 42'sinin ise tavsiye ile ilaç kullandığ saptanmıştır. Sonuç: Araştırma sonuçlarına göre; öğrencilerin akılcı ilaç kullanımında yetersiz olduğu söylenebilir.
\end{abstract}

Anahtar Kelimeler: Akılcı İlaç Kullanımı, Davranış, Üniversite Öğrencileri

\section{A Study on Rational Drug Use}

\begin{abstract}
Aim: This study aims to determine the behavior of rational drug use among university students.
\end{abstract}




\section{Akılcı İlaç Kullanımina İlişkin Bir Araştırma}

Method: The research population composed of 800 first and fourth-grade students at Faculty of Economics and Administrative Sciences in a public university. The research was conducted between 15 May-15 June 2016 and 602 people were involved in the study. Findings: This study showed that $52 \%$ of the students used drugs in the last month, $12 \%$ used drugs continuously and \%17 used drugs frequently. 13\% of students using drugs frequently did not know the drug name and painkillers were the most commonly used drug. In addition, it was found that $27 \%$ of participants received the drug without a prescription, $23 \%$ did not read the prescriptions, $24 \%$ did not use drugs on time and $13 \%$ made some changes in the dose of the drug used.

Results: The study demonstrated that $10 \%$ of the students used drugs in stressful situations and $42 \%$ used the recommended drugs. According to the results of the research the students was inadequate about rational drug use.

Keywords: Rational Drug Use, Behavior, University Students.

\section{Giriş}

İlaçlar, sağlık sisteminin önemli bileşenlerindendir ve hastaları tedavi etme ve yaşamları kurtarmada kritik rol oynamaktadır (Angamo et al., 2011). İlaçlar doğru kullanıldığında bozulan sağlık statüsünü eski haline getirmede önemli işlev görürken, yanlış kullanıldığında sağlık statüsünü daha da kötüleştirme ve sonunda ölüme götürme gibi riskleri bulunmaktadır. Bu nedenle ilaçların "akılcı" kullanımı gün geçtikçe önemi artan bir kavramdir.

Akılcı ilaç kullanımı, sağlık yönetim sistemlerinin bir parçasıdır ve kişilerin sağlık ve sosyo-ekonomik özelliklerine etki etmektedir (Amin et al., 2011). Akılcı ilaç kullanımı, ilaçlarla ilgili doğru ve tam bilgiye sahip olma ile yakından ilgilidir. Bu nedenle ilaçlarla ilgili objektif, tam, güncel, ulaşılabilir bilginin tüm taraflara sağlanması gereklidir (Çelik vd., 2013).

Akılcı ilaç kullanımı, Dünya Sağlık Örgütü (DSÖ) tarafından "kişilerin klinik bulgularına ve bireysel özelliklerine uygun ilacı, uygun süre ve dozda, en düşük fiyatta ve kolayca sağlayabilmeleri" şeklinde tanımlanmıştır (DSÖ, 1985). Bir başka tanımda akılcı ilaç kullanımı, ilaç tedavisinin etkili, güvenli ve ekonomik biçimde uygulanmasına olanak tanıyan, planlama, yürütme ve izleme sürecidir (Erkan Kılıç, 2013).

Akılcı ilaç kullanımı, DSÖ'nün uzun yıllardır gündeminde olup (Rostova et al., 2012), 1970'li y1llara kadar uzanmaktadır (Le Grand, 1999). 
Akılcı ilaç kullanımında sorumluluk hasta, doktor ve sağlık kurumu olmak üzere üç farklı ancak birbirinin tamamlayıcısı gruptadır (Prasad et al., 2014). Akılcı ilaç kullanımının sağlanabilmesi devletin, ilaç endüstrisinin, başta hekim ve eczacılar olmak üzere sağlık personelinin ve toplumun akılcı davranmasını gerektirmektedir (Özçelikay, 2001; Çelik vd., 2013). Akılcı ilaç kullanımı basamakları; doğru tanının konması, prognozun belirlenmesi, tedavi amaçlarının saptanması, tedavi seçeneklerinin gözden geçirilmesi, uygun tedavinin seçimi, ilaç tedavisi gerekli ise reçetenin doğru biçimde

Akılcı İlaç Kullanımina İlişkin Bir Araştırma yazımı ve takip şeklinde sıralanabilir (Maxwell, 2009).

Akılcı olmayan ilaç kullanımı dünya geneli için sorundur (Le Grand, 1999). Akılcı olmayan ilaç kullanımında, gelişmiş ülkelerde kapsamlı çalışma ve sorunun çözümünde belirli bir aşama kaydedilmiştir (Akıcı vd., 2002). Çeşitli adımlar atılmakla birlikte akılcı ilaç kullanımı kavramı gelişmekte olan ülkeler için yeni bir kavramdır (Amin et al., 2011). İlaçların akılcı olarak kullanılmaması nedeniyle oluşan zararlar gelişmekte olan ülkelerde daha yaygındır (Afriyle ve Raymond, 2014).

Akılcı olmayan ilaç kullanımını ortaya çıkaran faktörler olarak hizmet sunan ve alanın bilgi eksikliği, tıp eğitimindeki sorunlar, hekim-hasta etkileşimindeki yetersizlik, doğru teşhisin konulamaması, hastaların ilaç yazdırma baskıları, yasal mevzuat eksikliği ve ilaç firmalarının hizmet sunucular üzerindeki baskılarının neden olduğu ifade edilebilir (Ambwani ve Mathur, 2006).

İlaçların akılcı olmayan kullanımları sonucunda tedaviden beklenen yararın görülmemesi, çoklu ilaç kullanımı (polifarmasi), uygunsuz antibiyotik kullanımına bağlı gelişen antibiyotik direnci, kan yolu ile bulaşan hastalık riskinde artış, yanlış doz ya da doz aralığında kullanım, hastalık için doğru ilacın kullanılmaması gibi sorunlar ortaya çıkmaktadır (WHO, 2002; WHO, 2010). Gereksiz ve yanlış ilaç uygulamasının bir diğer sonucu ekonomik sorunlardır; yüksek ilaç harcamaları sosyal güvenlik kurumlarına ağır bir yük getirmekte, geri ödemede ciddi sorunlara yol açmaktadır(Aydın ve Gelal, 2012; Dolu, 2013).

Akılcı ilaç kullanımının sağlanmasında DSÖ tarafından şu hususlar önerilmektedir (DSÖ, 2007):

- İlaç kullanım politikalarını koordine edecek ve politikaların etkilerini takip edecek bir kurum oluşturulmalıdır.

- İlaçlarla ilgili karar süreçlerini destekleyecek kanita dayalı kılavuzlar geliştirilmelidir. 


\begin{tabular}{l} 
Akılcı İlaç \\
Kullanımına \\
İlişkin Bir \\
Araştırma \\
38 \\
\hline
\end{tabular}

- Temel ilaçlar listelenmeli ve ilaç geri ödemesi kapsamina alınmalıdır.

- Hastaneler ve çeşitli birimlerde ilaç komiteleri kurulmalıdır.

- Problem çözümüne yönelik eğitimler verilmelidir.

- Tıp eğitiminde gelişme sağlanmalıdır.

- Kurumlarda denetim sistemi geliştirilmelidir.

- İlaçlarla ilgili bağımsız veri sağlanmalıdır.

- Okullarda akılcı ilaç kullanımına ilişkin eğitim verilmelidir.

kaldırılmalıdır.

- Akılcı olmayan reçete yazımını teşvik eden teşvikler

- İlaç kullanımı ve sağlık personeline ulaşımda adalet sağlanmalıdır.

Akılcı ilaç kullanımının hekim ve sağlık kurumları dışında önemli taraflarından bir diğeri sağlık hizmeti kullanıcılarıdır. Akılcı ilaç kullanımının sağlanabilmesi için ilgili tarafların akılcı ilaç kullanma davranışlarının çeşitli araştırmalarla belirlenmesi gereklidir. Bu araştırmada bir devlet üniversitesinin iktisadi ve idari bilimler fakültesinde öğrenim gören öğrencilerin akılcı ilaç kullanma davranışları incelenmektedir.

\section{Yöntem}

$\mathrm{Bu}$ araştırmanın amacı, bir devlet üniversitesinin iktisadi ve idari bilimler fakültesinde öğrenim gören öğrencilerin akılcı ilaç kullanma davranışlarının belirlenmesidir. Öğrencilerin akılcı ilaç kullanma davranışları ile çeşitli özellikleri arasında ilişki olup olmadığının belirlenmesi de bu araştırmanın amaçları arasındadır. Araştırmanın evrenini bir devlet üniversitesinin iktisadi ve idari bilimler fakültesinde 4 yıllık eğitim veren İktisat, Kamu Yönetimi, Maliye, Çalışma Ekonomisi ve İşletme bölümlerinde öğrenim gören 800 birinci ve dördüncü sınıf öğrencileri oluşturmaktadır. Birinci ve dördüncü sınıf öğrencilerinin seçilmesinin nedeni, araştırmanın diğer amaçları yanında üniversite eğitimine yeni başlama ile son sınıfa gelmenin akılcı ilaç kullanımında farklılığa neden olup olmadığının da saptanmasıdır. Araştırmada beş bölümde birinci ve dördüncü sinıfta eğitim gören 800 öğrencinin tümüne ulaşılmak hedeflenmiştir. Kullanılan veri toplama aracı, 15 Mayıs 2016-15 Haziran 2016 tarihleri arasında araştırmacılar tarafından bölümler ve sınıflar gezilerek 
öğrencilere dağıtılmış ve toplam 602 adet geçerli ve kullanılabilir anketin geri dönüşü sağlanmıştır.

Araştırmada veri toplama aracı olarak anket formu kullanılmıştır. Anket formu toplam 24 sorudan oluşmaktadır. Araştırma formunda, öğrencilerin kişisel ve demografik bilgilerini ölçmeye yönelik 9 soru ve akılcı ilaç kullanma davranışlarını ölçmeye yönelik ise 16 soru yer almaktadır. Bu çalışmada, Kaya vd. (2015) tarafından geliştirilen ve uygulanan anket formu kullanılmıştır. Anketten elde edilen verilerin analizinde SPSS 20,0 paket programından yararlanılarak katılımcların bireysel özelliklerinin sunumunda tanımlayıcı istatistiksel yöntemlerden yararlanılmıştır. Katılımcıların çeşitli özellikleri ile akılcı ilaç kullanma davranışları arasındaki ilişkiyi ölçmek için Ki-Kare analizi uygulanmıştır.

\section{Bulgular}

Araştırma kapsamında yer alan öğrencilerin birseysel özelliklere göre dağılımı Tablo 1'te verilmektedir. Buna göre araştırmaya katılanların yaklaşık yarısı 21 yaşın altındadır. Cinsiyet açısından bakıldığında katılımcıların yarıdan fazlası $(\% 61,6)$ kadınlardan oluşmaktadır. Katılımcıların yaklaşık yarısı birinci sınıfta öğrenim görmektedir. Öğrencilerin öğrenim gördükleri bölümlere göre dağılımına bakıldığında dengeli dağılım görülmektedir. Katılımcıların \% 69,6'sının geliri giderini karşılarken \% 11,9'unun kronik hastalığı bulunmaktadır.

Tablo 1. Katılımcıların Bireysel Özellikleri

\begin{tabular}{lcc}
\hline Değişkenler & Sayı & $\%$ \\
\hline Yaş (Yıl) & & \\
$\quad \leq 21$ & 287 & 47,7 \\
$\geq 22$ & 315 & 52,3 \\
\hline Cinsiyet & & \\
$\quad$ Kadın & 371 & 61,6 \\
$\quad$ Erkek & 231 & 38,4 \\
\hline Öğrenim Görülen Sınıf & & \\
$\quad$ Birinci Sınıf & 296 & 49,2 \\
$\quad$ Dördüncü Sınıf & 306 & 50,8 \\
\hline Öğrenim Görülen Bölüm & & \\
İktisat & 120 & 19,9 \\
$\quad$ Kamu Yönetimi & 120 & 19,9 \\
$\quad$ Maliye & 121 & 20,1 \\
Çalışma Ekonomisi & 119 & 19,8 \\
İşletme & 122 & 20,3 \\
\hline
\end{tabular}


Tablo 1 Devamı

\section{Akılcı İlaç Kullanımina İlişkin Bir Araştırma}

\begin{tabular}{lcc}
\hline Ekonomik Durum & & \\
Gelir gideri karşllyyor & 419 & 69,6 \\
$\quad$ Gelir gidere yetmiyor & 183 & 30,4 \\
\hline Kronik Hastalık & & \\
$\quad$ Evet & 72 & 11,9 \\
$\quad$ Hayır & 530 & 88,1 \\
\hline Toplam & 602 & 100,0 \\
\hline
\end{tabular}

Tablo 2'de katılımcıların akılcı ilaç kullanma davranışları görülmektedir. Öğrencilerin yarıdan fazlası (\% 52,3) son 1 ay içinde ilaç kullanırken, \% 87'si sürekli ilaç kullanmamaktadır. 108 öğrenci sık ilaç kullanmakta ve sık ilaç kullananların \% 13'ü kullandığı ilacın adını bilmemektedir. Öğrencilerin sık kullandıkları ilaçlar ağrı kesici, antibiyotik, sakinleştirici ve vitamindir.

Öğrencilerin \% 62'si ağrı, \% 32,6'sı ise soğuk algınlığı nedeniyle ilaç kullanmaktadır. Katılımcıların \% 27,4'ü reçetesiz ilaç alırken, \% 23,6'sı reçeteleri okumamaktadır. İlaçları düzenli kullanmayanların oranı \% 24,3 olup, düzenli kullanmamanin birinci sebebi $(\% 32,2)$ unutma olarak ifade edilmiştir. İlaç kullanımında en fazla açlık tokluk durumuna dikkat edilmektedir. İlaç dozunda değişiklik yapanların oranı $\% \quad 13,8$ ve katılımcıların \% 72,9'u hastalık belirtisi geçtiğinde ilaç kullanımını bırakmaktadır. Öğrencilerin \% 10,6'ı stresli durumda, \% 42,4' ü ise tavsiye ile ilaç kullanmaktadır. Tavsiye ile ilaç kullanımında en yaygın olan ilaç ağrı kesicidir (\% 42,4).

Tablo 2. Katılımcıların Akılcı İlaç Kullanma Davranışları

\begin{tabular}{lcc}
\hline Davranışlar & Sayı & $\%$ \\
\hline Son 1 Ay İçinde İlaç Kullanma & & \\
$\quad$ Evet & 315 & 52,3 \\
$\quad$ Hayır & 287 & 47,7 \\
\hline Sürekli İlaç Kullanma & & \\
$\quad$ Evet & 74 & 12,3 \\
$\quad$ Hayır & 528 & 87,7 \\
\hline Sik İlaç Kullanma & & \\
$\quad$ Evet & 108 & 17,9 \\
$\quad$ Hayır & 494 & 82,1 \\
\hline Sik Kullanılan İlaç Adını Bilme & & \\
$\quad$ Evet & 94 & 87,0 \\
$\quad$ Hayır & 14 & 13,0 \\
\hline
\end{tabular}


Tablo 2. Devamı

\begin{tabular}{|c|c|c|}
\hline \multicolumn{3}{|l|}{ Sık Kullanılan İlaç Türü̈ } \\
\hline Ağrı Kesici & 321 & 53,3 \\
\hline Antibiyotik & 52 & 8,6 \\
\hline Sakinleştirici & 16 & 2,7 \\
\hline Vitamin & 26 & 4,3 \\
\hline \multicolumn{3}{|l|}{ İlaç Kullanma Nedeni ${ }^{*}$} \\
\hline Kronik Hastalık & 72 & 12,0 \\
\hline A ğn1 & 373 & 62,0 \\
\hline Soğuk Algınlığ 1 & 196 & 32,6 \\
\hline \multicolumn{3}{|l|}{ Reçetesiz İlaç Alma } \\
\hline Evet & 165 & 27,4 \\
\hline Hayır & 437 & 72,6 \\
\hline \multicolumn{3}{|l|}{ Reçete Okuma } \\
\hline Evet & 460 & 76,4 \\
\hline Hayır & 142 & 23,6 \\
\hline \multicolumn{3}{|l|}{ İlacı Zamanında Alma } \\
\hline Evet & 456 & 75,7 \\
\hline Hayır & 146 & 24,3 \\
\hline \multicolumn{3}{|l|}{ İlaç/İlaçları Zamanında Almama } \\
\hline \multicolumn{3}{|l|}{ Neden/Nedenleri ${ }^{*}$} \\
\hline Unutma & 194 & 32,2 \\
\hline Gereklilik hissettiğinde alma & 103 & 17,1 \\
\hline Önerilen dozu uygun bulmama & 9 & 1,5 \\
\hline İlaç içmeyi sevmeme & 46 & 7,6 \\
\hline İlacı yazdıramama & 5 & 0,8 \\
\hline İhmal etme & 47 & 7,8 \\
\hline \multicolumn{3}{|l|}{ İlaç Kullanımında Dikkat Edilen } \\
\hline \multicolumn{3}{|l|}{ Durumlar } \\
\hline Açlık-tokluk & 447 & 74,3 \\
\hline Saat aralıkları & 290 & 48,2 \\
\hline Dozu & 183 & 30,4 \\
\hline \multicolumn{3}{|l|}{ İlaç Dozunda Değişiklik Yapma } \\
\hline Evet & 83 & 13,8 \\
\hline Hayır & 517 & 86,2 \\
\hline \multicolumn{3}{|l|}{ İlaç Kullanmayı Bırakma* } \\
\hline Hastalık belirtileri geçtiğinde & 439 & 72,9 \\
\hline Tedavi dozu tamamlandığında & 155 & 25,7 \\
\hline İlacın yan etkisi oluştuğunda & 90 & 15,0 \\
\hline Başka bir rahatsızlık olduğunda & 15 & 2,5 \\
\hline Unuttuğumda & 35 & 5,8 \\
\hline Fazla ilaç almak istemediğimde & 29 & 4,8 \\
\hline \multicolumn{3}{|l|}{ Stresli Durumlarda İlaç Kullanımı } \\
\hline Evet & 64 & 10,6 \\
\hline Hayır & 538 & 89,4 \\
\hline
\end{tabular}

\section{Akılcı İlaç Kullanımına İlişkin Bir Araştırma}


Tablo 2. Devami

\section{Akılcı İlaç Kullanımina İlişkin Bir Araştırma}

42

\begin{tabular}{lcc}
\hline Tavsiye İle İlaç Kullanımı & & \\
Evet & 255 & 42,4 \\
Hayır & 347 & 57,6 \\
\hline Tavsiye ile Kullanılan İlaçlar & & \\
Ağrı kesici & 255 & 42,4 \\
Antibiyotik & 37 & 6,1 \\
Soğuk algınlığı & 104 & 17,3 \\
Multivitamin & 13 & 2,2 \\
Sakinleştirici & 5 & 0,8 \\
\hline
\end{tabular}

*Birden fazla seçenek işaretlenebilmektedir.

Tablo 3'te katılımcıların çeşitli temel özellikleri ile akılcı ilaç kullanımı arasındaki ilişkinin sınanması amacıyla yapılan Ki-Kare analizi sonuçları verilmektedir. Yaş değişkeni açısından incelendiğinde sürekli ve sık ilaç kullanımı, reçetesiz ilaç alımı ve reçete okuma, ilacı zamanında kullanma ve stresli durumlarda ilaç kullanımı yaşı 22 ve üzerinde olan katılımcılarda daha yüksek ancak istatistiksel olarak anlamlı değildir. Tavsiye ile ilaç kullanımı 21 ve altı yaş aralığında yer alanlarda istatistiksel olarak daha yüksektir. Sürekli ve sık ilaç kullanımı, reçetesiz ilaç alma ve reçete okuma kadınlarda, tavsiye ilaç kullanımı ise erkeklerde istatistiksel olarak anlamlı şekilde daha yüksektir.

Sürekli ve tavsiye yoluyla ilaç kullanımı ile öğrenim görülen sınıf arasında istatistiksel olarak anlamlı ilişki bulunmakta ve sürekli ilaç kullanımı dördüncü sınıflarda öğrenim gören öğrencilerde, tavsiye ile ilaç kullanma ise birinci sınıflarda öğrenim gören öğrencilerde daha yüksektir. Geliri giderini karşılamaya yetmeyen öğrencilerde sık ilaç kullanımı, reçetesiz ve tavsiye ile ilaç alma istatistiksel olarak anlamlı şekilde daha yüksek iken, ilacı zamanda kullanma ise geliri giderini karşılayan öğrencilerde daha yüksektir. Sürekli, sık ve stresli durumlarda ilaç kullanımı kronik hastalığı olan katılımcılarda istatistiksel olarak anlamlı şekilde daha yüksektir. 
İşletme Bilimi Dergisi (JOBS), 2017; 5(1): 35-48. DOI: 10.22139/jobs.286671

Tablo 3. Akılcı İlaç Kullanımının Katılımcıların Temel Özellikleri İle İlișkisi

\begin{tabular}{|c|c|c|c|c|c|c|c|c|}
\hline Değişkenler & $\begin{array}{l}\text { Sürekli } \\
\text { İlaç } \\
\text { Kullanımı }\end{array}$ & $\begin{array}{l}\text { Sık İlaç } \\
\text { Kullanımı }\end{array}$ & $\begin{array}{l}\text { Reçetesiz } \\
\text { İlaç Alma }\end{array}$ & $\begin{array}{l}\text { Reçete } \\
\text { Okuma }\end{array}$ & $\begin{array}{l}\text { İlacı } \\
\text { Zamanında } \\
\text { Kullanımı }\end{array}$ & $\begin{array}{l}\text { İlaç } \\
\text { Dozunda } \\
\text { Değişiklik }\end{array}$ & $\begin{array}{l}\text { Stresli } \\
\text { Durumlarda } \\
\text { İlaç } \\
\text { Kullanımı } \\
\end{array}$ & $\begin{array}{l}\text { Tavsiye İle } \\
\text { Illaç } \\
\text { Kullanma }\end{array}$ \\
\hline $\begin{array}{l}\text { Yaş }(Y i l) \\
\leq 21 \\
\geq 22\end{array}$ & $\begin{array}{l}32(11,1) \\
42(13,3) \\
\chi^{2}=0,664 \\
p=0,415\end{array}$ & $\begin{array}{l}49(17,1) \\
59(18,7) \\
\chi 2=0,280 \\
p=0,597\end{array}$ & $\begin{array}{l}74(25,8) \\
91(28,9) \\
\chi 2=0,728 \\
p=0,394\end{array}$ & $\begin{array}{l}213(74,2) \\
246(78,3) \\
\chi^{2}=1,416 \\
p=0,234\end{array}$ & $\begin{array}{l}213(74,2) \\
243(77,1) \\
\chi 2=0,700 \\
p=0,403\end{array}$ & $\begin{array}{l}42(14,7) \\
41(13,1) \\
\chi 2=0,333 ; 43 \\
p=0,564\end{array}$ & $\begin{array}{l}28(9,8) \\
36(11,5) \\
\chi^{2}=0,460 \\
p=0,498\end{array}$ & $\begin{array}{l}146(50,9) \\
109(34,7) \\
\chi 2=16,026 \\
p=0,000\end{array}$ \\
\hline $\begin{array}{l}\text { Cinsiyet } \\
\text { Kadin } \\
\text { Erkek }\end{array}$ & $\begin{array}{l}56(15,1) \\
18(7,8) \\
\chi 2=7,041 ; \\
\mathbf{p}=\mathbf{0}, 008\end{array}$ & $\begin{array}{l}79(21,3) \\
29(12,6) \\
\chi 2=7,386 ; \\
p=0,007\end{array}$ & $\begin{array}{l}102(27,5) \\
63(27,3) \\
\chi 2=0,003 ; \\
p=0,953\end{array}$ & $\begin{array}{l}304(81,9) \\
155(67,4) \\
\chi 2= \\
16,656 ; \\
\mathrm{p}=\mathbf{0}, 000\end{array}$ & $\begin{array}{l}274(73,9) \\
182(78,8) \\
\chi 2=1,886 ; \\
\mathrm{p}=0,170\end{array}$ & $\begin{array}{l}49(13,2) \\
34(14,8) \\
\chi 2=0,282 ; \\
p=0,595\end{array}$ & $\begin{array}{l}43(11,6) \\
21(9,1) \\
\chi 2=0,903 ; \\
p=0,342\end{array}$ & $\begin{array}{l}147(39,6) \\
108(47,0) \\
\chi 2=3,126 \\
p=0,047\end{array}$ \\
\hline $\begin{array}{l}\text { Öğrenim Görülen Sınıf } \\
\text { 1. Sinıf } \\
\text { 4. Sinıf }\end{array}$ & $\begin{array}{l}29(9,8) \\
45(14,7) \\
\chi 2=3,362 \\
\mathbf{p}=\mathbf{0 , 0 4 7}\end{array}$ & $\begin{array}{l}51(17,2) \\
57(18,6) \\
\chi 2=0,200 \\
p=0,655\end{array}$ & $\begin{array}{l}77(26,0) \\
88(28,8) \\
\chi 2=0,570 \\
p=0,450\end{array}$ & $\begin{array}{l}220(74,3) \\
239(78,4) \\
\chi 2=1,356 ; \\
p=0,244\end{array}$ & $\begin{array}{l}220(74,3) \\
236(77,1) \\
\chi 2=0,642 \\
p=0,423\end{array}$ & $\begin{array}{l}47(15,9) \\
36(11,8) \\
\chi 2=2,145 \\
p=0,143\end{array}$ & $\begin{array}{l}31(10,5) \\
33(10,8) \\
\chi 2=0,019 \\
p=0,890\end{array}$ & $\begin{array}{l}160(54,1) \\
95(31,1) \\
\chi 2=32,268 ; \\
\mathbf{p}=\mathbf{0 , 0 0 0}\end{array}$ \\
\hline $\begin{array}{l}\text { Ekonomik Durum } \\
\text { Gelir gideri karşılıyor } \\
\text { Gelir gidere yetmiyor }\end{array}$ & $\begin{array}{l}45(10,7) \\
29(15,8) \\
\chi 2=3,081 \\
p=0,079\end{array}$ & $\begin{array}{l}63(15,0) \\
45(24,6) \\
\chi 2=7,898 \\
p=0,005\end{array}$ & $\begin{array}{l}106(25,3) \\
59(32,2) \\
\chi 2=3,085 \\
\mathbf{p}=\mathbf{0}, \mathbf{0 4 9}\end{array}$ & $\begin{array}{l}323(77,3) \\
136(74,3) \\
\chi 2=0,616 ; \\
p=0,432\end{array}$ & $\begin{array}{l}327(78,0) \\
129(70,5) \\
\chi 2=3,953 \\
p=0,047\end{array}$ & $\begin{array}{l}57(13,6) \\
26(14,3) \\
\chi 2=0,045 \\
p=0,832\end{array}$ & $\begin{array}{l}39(9,3) \\
25(13,7) \\
\chi 2=2,509 \\
p=0,113\end{array}$ & $\begin{array}{l}166(39,7) \\
89(48,6) \\
\chi 2=4,147 \\
\mathbf{p}=\mathbf{0}, \mathbf{0 4 2}\end{array}$ \\
\hline $\begin{array}{l}\text { Kronik Hastalik } \\
\text { Evet } \\
\text { Hayır }\end{array}$ & $\begin{array}{l}20(47,6) \\
54(9,6) \\
\chi 2=52,263 \\
\mathbf{p}=\mathbf{0 , 0 0 0}\end{array}$ & $\begin{array}{l}26(61,9) \\
82(14,6) \\
\chi 2=59,280 \\
p=0,000\end{array}$ & $\begin{array}{l}16(38,1) \\
149(26,6) \\
\chi 2=2,592 ; \\
p=0,107\end{array}$ & $\begin{array}{l}32(76,2) \\
427(76,4) \\
\chi 2=0,001 \\
p=0,977\end{array}$ & $\begin{array}{l}32(76,2) \\
424(75,7) \\
\chi 2=0,005 \\
p=0,945\end{array}$ & $\begin{array}{l}6(14,3) \\
77(13,8) \\
\chi 2=0,008 \\
p=0,930\end{array}$ & $\begin{array}{l}11(26,2) \\
53(9,5) \\
\chi 2=11,463 \\
p=0,001\end{array}$ & $\begin{array}{l}19(45,2) \\
236(42,2) \\
\chi 2=0,146 \\
p=0,703\end{array}$ \\
\hline
\end{tabular}

Akılcı İlaç

Kullanımına

İlişkin Bir

Araştırma 


\section{Akılcı İlaç Kullanımina İlişkin Bir Araştırma}

\section{Tartışma ve Sonuç}

$\mathrm{Bu}$ araştırma, üniversite öğrencilerinin akılcı ilaç kullanım davranışlarının belirlenmesi amacıyla gerçekleştirilmiştir. Araştırmanın bu amacı doğrultusunda, bir devlet üniversitenin iktisadi ve idari bilimler fakültesinde öğrenim gören öğrenciler çalışmanin evreni oluşturmuştur. Üniversite eğitiminin akılcı ilaç kullanımında fark yaratıp yaratmadığının belirlenmesi de hedeflendiğinden bu çalışmanın kapsamına birinci ve dördüncü sınıf öğrenciler dâhil edilmiş ve evrendeki 800 öğrenciden 602'si ile görüşme gerçekleştirilmiştir.

Araştırma sonucunda öğrencilerin \% 52'sinin son bir ay içerisinde, $\%$ 12 'sinin sürekli ve \% 17'sinin sık ilaç kullandığ1 ve \% 13'ünün sık kullandıkları ilacın adını bilmediği belirlenmiştir. Kaya vd., (2015) tarafından gerçekleştirilen çalışmada, öğrencilerin \% 50'sinin son bir ay içerisinde, \% 13'ünün sürekli ve \% 27'sinin sık ilaç kullandığı; Yılmaz vd. (2008) tarafından yapılan çalışmada ise katılımcıların \% 26'sının son bir ay içerisinde ilaç kullandığı saptanmıştır. Bu sonuçlar, genç bir grubu temsil etmeleri ve bunun sonucunda daha az ilaç kullanmaları beklenen üniversite öğrencilerinin beklenenden fazla ilaç kullandıklarını göstermektedir.

Araştırmanın bir diğer bulgusu, öğrencilerin en sık kullandıkları ilacın ağrı kesici (\% 53,3) olmasıdır. Kaya vd. (2015) tarafından gerçekleştirilen çalışmada da öğrencilerin en sık kullandıkları ilacın ağrı kesici $(\%$ 81,3) olduğu saptanmıştır. Bu duruma ağrı kesicilerin reçetesiz olarak alınabilmelerinin, yan etkilerinin daha az olduğunun düşünülmesinin ve fiyatlarının ödenebilir olmasının neden olduğu düşünülmektedir.

Öğrencilerin \% 27,4'ünün reçetesiz olarak ilaç aldığı belirlenmiştir. Baş vd. (2013) tarafından tıp fakültesi öğrencilerinin reçetesiz ilaç kullanımlarının değerlendirildiği çalışmada, öğrencilerin \% 41,9'unun son bir ay içerisinde reçetesiz olarak ilaç aldıkları bulgusuna ulaşılmıştır. Karakurt vd. (2010) tarafından gerçekleştirilen çalışmada ise öğrencilerin \% 23'ünün ve Yapıcı vd. (2011) tarafından yapılan çalışmada ise katılımcıların \% 31,3'ünün reçetesiz olarak ilaç kullandıkları belirlenmiştir. Reçetesiz ilaç kullanımı, uygun olmayan kullanıma, doğru tanı ve tedavinin gecikmesine, ilaç direncinin gelişmesine ve bireyin sınırlı gelirinin gereksiz harcanması gibi sonuçlara neden olabilmektedir (Kaya vd., 2013).

Araştırma kapsamındaki öğrencilerin \% 23,6'sının reçeteleri okumadığı belirlenmiştir. Özyiğit ve Arıkan (2015) tarafından yapılan çalışmada, kullanma talimatını okuyanların oranının \% 63, Kaya vd. (2015) tarafından reçeteleri okumayanların oranının ise \% 9,4 olduğu belirlenmiştir. 
Kullanılan ilacın etkinliğinin artırılması ve ilaçtan beklenen yararın sağlanması için reçetelerin ve kullanma talimatlarının okunması gereklidir.

Öğrencilerin \% 24,3'ünün ilacı zamanında kullanmadığı ve ilacı zamanında kullanmama nedeninde ilk sırayı (\% 32,2) unutma almaktadır. Yılmaz vd. (2011) tarafından yapılan çalışmada, katılımcıların \% 12,5'inin ilaçları zamanında kullanmadıkları ve zamanında kullanmanın en yaygın (\% 69) nedeninin unutma olduğu saptanmıştır. Etkin tedavinin sağlanması için ilaçların zamanında kullanımı gerekmekte ve ilaçların zamanında kullanılmaması tedavi sürecinin uzamasına ve ek tedavilere neden olmaktadır.

Araştırma kapsamında yer alan öğrencilerin \% 13,8'inin ilaç dozunda değişiklik yaptığı belirlenmiştir. Yapıcı vd. (2011) tarafından yapılan çalışmada, katılımcıların \% 9,5'i, Yılmaz vd. (2008) tarafından yapılan çalışmada ise \% 43'ünün ilaç dozunda değişiklik yaptı̆̆ı saptanmıştır. İlaç dozunda değişiklik yapılması, olumsuz tıbbi sonuçlara neden olabileceğinden ilacın tedavi sürecinde önerilen dozda kullanılması sağlanmalıdır.

Araştırmanın bir diğer bulgusu, öğrencilerin \% 72,9'unun hastalık belirtileri geçtiğinde ilaç kullanmayı bırakmalarıdır. Karakurt vd. (2010) tarafından yapılan çalışmada katılımcıların \% 47,9'u, Yapıcı vd. (2011) tarafından yapılan çalışmada \% 43'ü, Kaya vd. (2015) tarafından yapılan çalışmada ise \% 62,2'si hastalık semptomları geçtiğinde ilaç kullanmayı bırakmaktadırlar. Bu sonuçlar, tedavinin sonuçlanmasından önce ilaç kullanımının bırakılmasının yüksek oranda olduğunu göstermekte ve bu durumun hastalığın tekrarlaması, ilaca direncin artması, sağlık hizmetinin gereksiz yere tekrar kullanımına yol açması gibi sonuçlara neden olabileceği söylenebilir.

Öğrenciler okul ve aile yaşamlarında çeşitli nedenlerle stresli hissedebilmektedirler. Araştırma kapsamında yer alan öğrencilerin \% 10 'unun stresli durumlarda ilaç kullandığı belirlenmiştir. Karakurt vd. (2010) tarafından yapılan çalışmada katılımcıların \% 7,8'i, Kaya vd. (2015) tarafından yapılan çalışmada ise \% 12,4'ü stresli durumlarda ilaç kullandığ saptanmıştır. Stresli durumlarda ilaç kullanımının yerine bireysel stresle mücadele yolları öğretilmelidir.

Asimetrik bilgi nedeniyle yönlendirilme söz konusu olabilmekte ve kişiler birbirlerinden etkilenerek sağlık kurumu ve hekim seçimi, ilaç kullanımı gibi davranışlarda bulunmaktadırlar. Bu çalışmada katılımcıların \% 42,4'ünün tavsiye ile ilaç kullandığı ve tavsiye ile kullanım yaygınlığı en yüksek olan (\% 42,4) ilacın ağrı kesiciler olduğu belirlenmiştir. Tavsiye ile 


\section{Akılcı İlaç Kullanımına İlişkin Bir Araştırma}

\section{6}

ilaç kullanma Özkan vd. (2005) tarafından yapılan çalışmada \% 25,6 olarak belirlenmiştir. Yılmaz (2011) tarafından gerçekleştirilen çalışmada, katılımcıların \% 24,7'si başkalarına iyi gelen ilacı kullandıklarını ifade etmişlerdir. Tavsiye ile ilaç kullanımı hastalığın tedavi edilmemesi, yeni sağlık sorunlarının ortaya çıkması gibi sonuçlara neden olabilmekte ve bu nedenle tavsiye ile ilaç kullanım alışkanlığının önüne geçilmesine gayret edilmelidir.

Akılcı ilaç kullanımının katılımcıların temel özellikleri ile ilişkisini belirlemeye yönelik analizler sonucunda tavsiye ile ilaç kullanımı yaşı 21 ve altında olanlar daha yüksek olup, bu duruma yaş ilerledikçe ilaçlar konusunda bilinç düzeyinin artmasının ve yönlendirilmeye daha az açı olunmasının neden olduğu söylenebilir. Sürekli ve sık ilaç kullanımı, reçete okuma ve tavsiye ile ilaç kullanımı istatistiksel olarak anlamlı şekilde kadınlarda daha yüksektir. Bu durum erkek öğrencilerin kızlara göre akılcı ilaç kullanma davranışlarının daha fazla geliştiğini göstermektedir. Sürekli ilaç kullanımı dördüncü sınıflarda, tavsiye ile ilaç kullanımı ise birinci sınıflarda daha yüksektir. Yaşın artışı ile akut ve kronik hastalıkların görülme riskinin artması nedeniyle dördüncü sınıflarda ilaç kullanımının daha yüksek olduğu düşünülmektedir. Dördüncü sinıflarda tavsiye ile ilaç kullanımının birinci sınıflara göre daha düşük olması diğer faktörlerin yanında eğitimin bilinç düzeyini artırmasıyla ilgili olduğu ifade edilebilir.

Geliri giderini karşılamaya yetmeyen öğrencilerde sık ilaç kullanımı, reçetesiz ilaç alma, tavsiye ile ilaç kullanımı daha yüksek ve ilacı zamanında kullanma ise daha düşüktür. Gelirin yetmemesi sürekli stres yaşamaya neden olarak öğrencilerde fiziksel ve psikolojik rahatsılıklara yakalanma riskini artırabilmekte ve bu durum öğrencilerin daha fazla ilaç kullanmasına yol açabilmektedir. Ayrıca, sağlık hizmeti kullanımı sağlık sigortası kapsamında olunması durumunda dahi katkı payını gerektirmektedir. Bu durumun geliri giderine yetmeyen öğrencileri reçetesiz ve tavsiye yoluyla ilaç kullanımına yönelttiği söylenebilir. Sürekli, sık ve stresli durumlarda ilaç kullanımı kronik hastalığı olan öğrencilerde daha yüksektir. Kronik hastalığın sağlık hizmeti ve ilaç kullanım gerekliliğini artırması kronik hastalığı olan öğrencilerde ilaç kullanımını yükseltmektedir.

$\mathrm{Bu}$ araştırma öğrencilerin akılcı ilaç kullanma bilinç düzeylerinin ve davranışlarının geliştirilmesi gerektiğini göstermektedir. Akılcı olmayan ilaç kullanımının hem sağlık statüsü hem de sağlık sektörü ve ekonomiye olumsuz etkileri bulunmaktadır. Akılcı ilaç kullanımına yönelik olarak okullarda ders, seminer vb. gibi araçlardan yararlanılmalı, internet, TV gibi araçlarda gereksiz ilaç kullanımını teşvik eden reklam ve programların sınırlanması gibi uygulamalar önerilebilir. 


\section{Kaynakça}

Afriyie, D. ve Tetteh, R. (2014). A Description of the Pattern of Rational Drug Use in Ghana Police Hospital. International Journal of Pharmacy and Pharmacology, 3(1): 143-148.

Akıcı, A., Uğurlu, M. Ü., Gönüllü, N., Oktay, Ş. ve Kalaça, S. (2002). Pratisyen Hekimlerin Akılcı İlaç Kullanımı Konusunda Bilgi ve Tutumlarının Değerlendirilmesi. Sted, 11(7): 253-257.

Ambwani, S. ve Mathur A.K. (2006). Rational Drug Use. Health Administrator, 19(1): 5-7.

Amin, A., Khan, M. A., Azam, S. M. F. ve Haroon, U. (2011). Review of Prescriber Approach Towards Rational Drug Practice in Hospitalised Patients. Journal of Ayub Medical College Abbottabad, 23(1): 19-22.

Angamo, M. T., Wabe, N. T. ve Raju, N. J. (2011). Assessment of Patterns of Drug Use by Using World Health Organization's Prescribing, Patient Care and Health Facility İndicators in Selected Health Facilities in Southwest Ethiopia. Journal of Applied Pharmaceutical Science, 1(7): 62-66.

Aydın, B. ve Gelal, A. (2012). Akılcı İlaç Kullanımı: Yaygınlaştııılması ve Tıp Eğitiminin Rolü. DEÜ Tip Fakültesi Dergisi, 26 (1): 57-63.

Baş, F. Y., Cankara, F. N. ve Yeşilot, Ş. (2013). Tıp Fakültesi Öğrencilerinde Reçetesiz İlaç Kullanımının Değerlendirilmesi. SDÜ Sağlık Bilimleri Dergisi, 4(2): 46-53.

Çelik, E., Şencan, M. N. ve Clark, M. P. (2013). Factors Affecting Rational Drug Use (Rdu), Compliance and Wastage. Turkish Journal Of Pharmaceutical Sciences, 10(1): 151-170.

Dolu, İ. (2013). Akılcı İlaç Kullanımı: Hollanda Örneği. Hacettepe Üniversitesi Eczacıllk Fakültesi Dergisi, 33(2): 179-202.

Erkan Kılıç, L. (2013). Akılcı İlaç Kullanımı. Ulusal Akciğer Kanseri (Kongre Kitabı), (Edt. Mandel MN., Ece T.), Kapadokya. 14-17 Mart,15-17.

Karakurt, P., Hacıhasanoğlu, R., Yıldırım, A. ve Sağlam, R. (2010). Üniversite Öğrencilerinde İlaç Kullanımı. TAF Preventive Medicine Bulletin, 9(5): 505-512.

Kaya, H., Turan, N., Keskin, Ö., Tencere, Z., Uzun, E., Demir, G. ve Yılmaz, T. (2015). Üniversite Öğrencilerinin Akılcı İlaç Kullanma Davranışları. Journal of Anatolia Nursing and Health Sciences, 18(1): 35-42.

Le Grand, A., Hogerzeil, H. V. ve Haaijer-Ruskamp, F. M. (1999). Intervention Research in Rational Use of Drugs: A Review. Health Policy and Planning, 14(2): 89-102.

Maxwell, S. (2009). Rational Prescribing: The Principles of Drug Selection. Clinical Medicine, 9(5): 481-485.

\section{Akılcı İlaç Kullanımına İlişkin Bir Araştırma}




\section{Akılcı İlaç Kullanımina İlişkin Bir Araştırma}

\section{8}

Özçelikay, G. (2001). Akılcı İlaç Kullanımı Üzerinde Bir Pilot Çalışma. Ankara Eczacılık Fakültesi Dergisi, 30(2): 9-18.

Özkan, S. vd. (2005). Bir Üniversite Hastanesine Başvuran Hastaların Hasta Olduklarındaki Tutumları ve İlaç Kullanım Alışkanlıkları. TAF Preventive Medicine Bulletin, 4(5): 223-237.

Özyiğit, F. ve Arıkan, İ. (2015). Kütahya İlinde Üniversite Öğrencilerinin Akılcı İlaç Kullanımı Hakkında Bilgi, Tutum ve Davranışları. Bozok Tıp Dergisi, 5(1): 4752.

Prasad,N., Jagadeesh, K. ve Revankar, S. (2014). Study of Rationality of Prescriptions \& Analysis of Drugs Prescribed Among in-Patients of Mcgann Teaching Hospital, S.I.M.S, Shimoga, Karnataka, India. IOSR Journal of Dental and Medical Sciences (IOSR-JDMS), 13 (7): 30-35.

Rostova, N. B., ve Odegova, T. F. (2012). Rational Use of Drugs: Pharmaceutical Aspects of the Drug Selection. Internatıonal Journal, 2(3): 237-241.

DSÖ (1985, 25-29 November). The Rational Use of Drugs. Conference of Experts on The Rational Use of Drugs. Retrieved from, http://apps.who.int/medicinedocs/documents/s17054e/s17054e.pdf

DSÖ (2002). Promoting Rational Use of Medicines: Core Components, World Health Organization.

DSÖ (2010). Health Systems Financing, the Path to Universal Coverage, Achieving Better Health Outcomes and Efficiency Gains Through Rational Use of Medicine. The World Health Report, Technical Brief Series - Brief No 3.

WHO, (2007). Progress in the Rational Use of Medicines, A60/24, 1-4.

Yapıcı, G., Balıkçı, S. ve Uğur, Ö. (2011). Birinci Basamak Sağlık Kuruluşuna Başvuranların İlaç Kullanımı Konusundaki Tutum ve Davranışları. Dicle Tıp Dergisi, 38(4): 458-465.

Yılmaz, E., Yılmaz, E., Karaca, F., Uçar, S. ve Yüce, T. (2008). Sağlık Yüksekokulu Öğrencilerinin İlaç Kullanma Durumlarının İncelenmesi. Firat Sağ lık Hizmetleri Dergisi, 3(8): 69-83.

Yılmaz, M., Güler, N., Güler, G. ve Kocataş, S. (2011). Bir Grup Kadının İlaç Kullanımı İle İlgili Bazı Davranışları: Akılcı Mı?. Cumhuriyet Tıp Dergisi, 33: 266-277. 